\title{
Apoptotic cell and phagocyte interplay: recognition and consequences in different cell systems
}

\author{
MARIA ELISABETE C. MOREIRA ${ }^{1}$ and MARCELLO A. BARCINSKI ${ }^{1,2}$ \\ ${ }^{1}$ Divisão de Medicina Experimental, Instituto Nacional de Câncer, 20231-050 Rio de Janeiro, RJ, Brasil \\ ${ }^{2}$ Instituto de Ciências Biomédicas, Universidade de São Paulo, 05508-900 São Paulo, SP, Brasil \\ Manuscript received on December 1, 2003; accepted for publication on December 3, 2003; \\ contributed by MARCELlO A. BARCINSKI*
}

\begin{abstract}
Cell death by apoptosis is characterized by specific biochemical changes, including the exposure of multiple ligands, expected to tag the dying cell for prompt recognition by phagocytes. In non-pathological conditions, an efficient clearance is assured by the redundant interaction between apoptotic cell ligands and multiple receptor molecules present on the engulfing cell surface. This review concentrates on the molecular interactions operating in mammalian and non-mammalian systems for apoptotic cell recognition, as well as on the consequences of their signaling. Furthermore, some cellular models where the exposure of the phosphatidylserine (PS) phospholipid, a classical hallmark of the apoptotic phenotype, is not followed by cell death will be discussed.
\end{abstract}

Key words: cell death, apoptosis, apoptotic cell recognition, apoptotic mimicry, phagocyte, intracellular signaling.

\section{INTRODUCTION}

Programmed cell death (PCD), as part of the normal cell physiology as are proliferation and differentiation, has been recognized for more than three decades. The concept of "programmed" cell death was first utilized by development biologists who used the term to refer to a predictable onset of cell death during tissue remodeling in development and metamorphosis. It referred to cellular changes in response to hormone levels oscillation and growth factor withdrawal, but did not refer at all to the pre lethal changes that we now use to characterize the different types of cell death (Zakeri 1998). Recently, advances in the field of cellular and molecular biol-

* Member of Academia Brasileira de Ciências Correspondence to: Maria Elisabete C. Moreira E-mail: mariacm@inca.gov.br ogy has made possible the characterization of the modulating genes, the signaling molecules and the cellular and molecular responses that together play fundamental roles in the recognition of the dying cell and its clearance by phagocytes. Thirty years ago, Schweichel and Merker (1973) described three morphologically distinct types of cell death in developing mammalian tissues with no definition, at that time, of the controlling genes implicated in the phenomenon. Considering mainly the morphological features attributed then to the dying cells, one can make a parallel with the three recently described types of PCD (Ogier Denis and Codogno 2003). At least in two types of PCD, type I (apoptosis) and type II (autophagy), the membrane remains intact during the progression of cell death with no damage to the neighboring cells. Classical type I apopto- 
sis is thus a morphological phenotype of PCD characterized by rapid condensation of cytoplasm and nuclear chromatin, resulting in DNA fragmentation and membrane blebbing followed by fragmentation of the cells in apoptotic bodies, constituted by condensed cytoplasm, nuclear material and/or whole organelles surrounded by intact plasma membrane. The concomitant biochemical changes experienced by apoptotic cells, starting from their initial injury by an appropriate stimulus to their recognition and clearance by phagocytes, are not in the scope of this review and have been widely reviewed elsewhere (Hengartner 2000, Geske and Gerschenson 2001).

Type II autophagic or lysosomal cell death starts with the sequestration of cytoplasmic material, including organelles, by a multilayer membrane to form an autophagosome, which in turn can receive inputs from the cellular endocytic pathway to form a hybrid organelle called amphisome. The expansion of the lysosomal system followed by selective clearance of specific cell organelles by the autophagic vacuoles, plays an important role in cytoplasmic homeostasis (for reviews see Ogier Denis and Codogno 2003, Wang and Klionsky 2003). It has been suggested that autophagy can somehow modulate the intracellular pool of active mitochondria, and thus be involved in mitochondria-dependent processes such as the execution of type I apoptotic cell death. A role of autophagy in helping cells to escape from apoptosis via the sequestration of cytochrome $\mathrm{c}$ has been suggested in the maturation of erythroid cells (Takano Ohmuro et al. 2000). The molecular machinery that regulates autophagy was first described in the yeast Saccharomyces cerevisiae, with the discovery of the APG (autophagy) and AUT (autophagocytosis) genes (Thumm et al. 1994), and is partially conserved in humans.

Type III PCD or cytoplasmic cell death is less frequently observed and poorly understood at the molecular level, but it has been related mainly to the neuronal cell death (Cunningham 1982, Oppenheim 1991, Bursch 2001). Indeed it became clear that the distinction between the three types of cell death here described is not always clear-cut. Dying cells may display a mixture of some morphological and/or molecular features associated to more than one of the mentioned types of PCD (Amarante Mendes et al. 1998, Sperandio et al. 2000). Further characterization of the distinct forms of apoptotic and non-apoptotic PCD will certainly lead to new insight into cell death programs and their roles in development and on the evolutionary relationship between them.

During the last thirty years, since the first mention of the apoptotic cell phenotype and its physiological implications in tissue development by Kerr et al. (1972), a lot has been added to our current knowledge about the molecular and cellular events that contribute to the apoptotic morphological features and to the exposure of cell-killing signals that shape apoptotic cell to further phagocyte recognition. The present review will mainly concentrate on the interactions between the "eat-me" signals displayed by apoptotic cells and their respective recognition molecules on phagocytes, eventually mediated by bridging molecules. The evolutionary conservation of some apoptotic cell ligands, receptors and signaling molecules will also be discussed.

\section{APOPTOTIC CELL RECOGNITION IN MAMMALIAN SYSTEMS: REDUNDANCY}

The importance of apoptotic cell recognition and clearance by phagocytes to tissue homeostasis is corroborated by the vast redundancy of ligands and receptors involved. Since the identification of the macrophage vitronectin receptor $\left(\alpha_{\mathrm{V}} \beta_{3}\right.$ integrin) as the first receptor to recognize and engulf apoptotic cells (Savill et al. 1990), several in vitro studies have characterized the participating molecules, mainly by inhibitory studies of the phagocytic process. The apoptotic cell is capped by various "eat-me" signals, that are recognized simultaneous or alternatively by distinct receptor molecules displayed by phagocytes (Figure 1). Indeed, the same ligand can be recognized by different receptors or bridging molecules, so that recognition possibilities are widely amplified. This redundancy aims to assure maximum clearance efficiency and explains the in- 
ability of some individual deletions to efficiently impair apoptotic cell clearance in vivo. It has also been observed some tissue-specific differences between the recognition molecules. For example, the presence of the bridging molecule C1q, the first component of complement, can be crucial for apoptotic cell clearance in the kidney (Taylor et al. 2000) but not in the skin (Pickering et al. 2001) of C1q-deficient mice. These findings point out to the need of detailed in vitro studies of different tissues, from mouse with genetic deletions of the different molecules involved in apoptotic cell clearance.

The receptors involved in target cell recognition have been mainly characterized by inhibitory studies of in vitro phagocytosis and the assays are made with relatively purified populations of phagocytes. Some of the receptors can act in concert to improve uptake efficiency (Pradhan et al. 1997) and can also interact with different ligands, triggering distinct intracellular signaling. The membrane glycoprotein CD14, present on the surface of mammalian macrophages, for example, can generate both inflammatory or anti-inflammatory responses after interaction with "non-self', lipopolysaccharide (LPS) or "self"' apoptotic cells, respectively (Devitt et al. 1998). One of the most important questions relates to the in vivo relevance of data obtained from in vitro studies. One must have in mind that the cell culture models used in apoptotic cell clearance studies may not be physiological since they might lack neighboring alternative phagocytes or bridging molecules present in vivo. It has been suggested that due to its high efficiency, one can only notice apoptotic cell clearance in vivo when it is defective (P.M. Henson, personal communication). Indeed, there have been few descriptions of defective clearance of apoptotic cells in vivo that corroborate in vitro studies (Botto et al. 1998, Taylor et al. 2000, Hamon et al. 2000, Scott et al. 2001, Teder et al. 2002, Vandivier et al. 2002). Taylor et al (2000) made the first description of in vivo impairment of apoptotic cell phagocytosis, analyzing the phagocytic capacity of C1q-deficient mouse macrophages. Other C1q-related molecules, known as collectins, nor- mally involved in non-self pattern recognition and consequent host protection from infectious organisms (Holmskov et al. 1994, Hansen and Holmskov, 1998), also play an important role in in vivo clearance of apoptotic cells. The abundance of the collectin surfactant protein D (SP-D) in the lung (Mason et al. 1998) probably justifies its role in the clearance of apoptotic cells from the naive murine lung (Vandivier et al. 2002). The transmembrane adhesion protein CD44, receptor for the non-sulfated glycosaminoglycan hyaluronan (HA) (Aruffo et al. 1990), was found to be also important for the resolution of lung inflammation, which was impaired by persistent accumulation of apoptotic neutrophils and decreased activation of transforming growth factor - $\beta_{1}$ (TGF- $\beta_{1}$ ) in CD-44 deficient mice (Teder et al. 2002). A very elegant combination of in vivo lossof-function and in vitro gain-of-function approaches was made by Hamon et al. (2000), showing that the ATP-binding-cassette transporter 1 (ABC1) modulates the rearrangement of the phospholipid phosphatidylserine (PS) in both the dying cell and the phagocyte membranes and also promotes engulfment of apoptotic cells. The modulation of apoptotic cell clearance has been shown to also be mediated by the Mer receptor tyrosine kinase, in macrophages from Mer-deficient mouse (Scott et al. 2001). However of course the in vitro studies allows for an indepth analysis of the molecular and cellular interactions involved in apoptotic cell recognition, signaling and clearance, as will be described below.

The characterization of receptor molecules and the intracellular signaling displayed by and transmitted to phagocytes from collectins and collectin-like bridging molecules (denoted as defense collagens), have progressed by virtue of some very elucidative in vitro studies. It was elegantly shown that the collectin mannose binding lectin (MBL) binds to apoptotic cells in a clustered pattern and initiates their uptake by phagocytes (Ogden et al. 2001). Its close relative, C1q, can attach to both viable and apoptotic cells, but only the latter are engulfed by macrophages. This difference has been attributed to the uniform distribution of $\mathrm{C} 1 \mathrm{q}$ on the surface of 


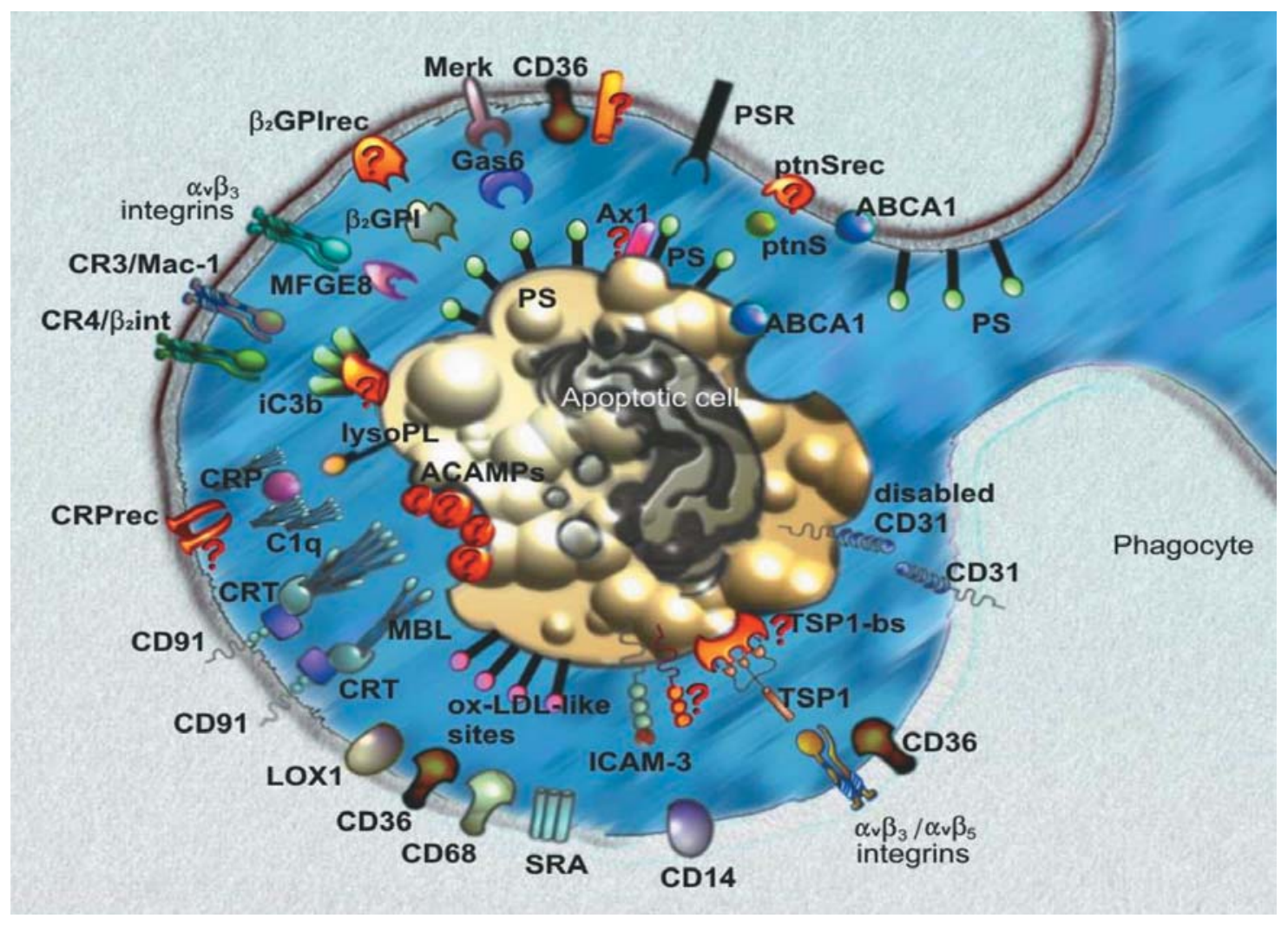

Fig. 1 - Redundancy in apoptotic cell and phagocyte interplay. Both cells display the proteins CD31 and ATP-binding cassete transporter (ABC A1) and the PS phospholipid on their external surface. Apoptotic cell PS can be recognized by a specific receptor (PSR) displayed by phagocyte, and also by the bridging molecules milk-fat globule epidermal growth factor 8 (MFGE8), growth arrest specific gene 6 (Gas6), $\beta_{2}$-glycoprotein I ( $\beta_{2}$-GP I) and protein S, which bind respectively to the $\alpha_{v} \beta_{3}$ integrin, Merk, $\beta_{2}$-GP I and protein S receptor molecules. Annexin I and CD36 seem also to be involved in PS recognition. Several scavenger receptors (oxidized low-density lipoprotein receptor 1 (LOX1), CD36, CD68 and SRA) recognize oxidized-LDL-like sites on apoptotic cell surface. The C1q and Mannose Binding Lectin (MBL) collectins modulate the recognition of Apoptotic Cell Associated Molecular Patterns (ACAMPs) via calreticulin (CRT) and CD91; C1q also participate in the interaction between lysophospholipids (lysoPLs) exposed by the dying cell and the reactive $\mathrm{C}$ protein. iC3b molecules are distributed in patches on the dying cell are recognized by the CR3/CD11b-CD18/Mac-1 and CR4/CD11c-CD18/ $\beta_{2}$ integrin glycoproteins. The $\alpha_{v} \beta_{3} / \alpha_{v} \beta_{5}$ integrins associate to CD36 and interact with trombospondin 1 (TSP 1), which is recognized by still uncharacterized binding sites on apoptotic cell surface. The membrane glycoprotein CD14 interacts with, but not only, the intercellular adhesion molecule 3 (ICAM-3). The surface protein CD31 signaling is disabled in apoptotic cells, promoting their tethering to and engulfment by phagocytes. Still uncharacterized surface molecules are indicated with a question mark. See details in the text.

non-apoptotic cells and the apparent need of high local concentration of ligands in order to attain optimal interaction with the phagocyte receptor (Ogden et al. 2001). The surface ligands involved in apoptotic cell binding to collectins are still uncharacterized, although surface structures on membrane blebs have been implicated. Also, apoptotic cell treatment with mannosidase or addition of high concentrations of mannose in the culture medium decreased its uptake by phagocytes. Inhibitory studies implicated the collagenous tail for $\mathrm{C} 1 \mathrm{q}$ receptor $(\mathrm{cClqR})$ or calreticulin (CRT) molecule as responsible for $\mathrm{Clq}$ and 
MBL binding on the macrophage surface, which in turn is bound to the multifunctional receptor CD91, also known as the $\alpha 2$-macroglobulin $(\alpha 2 \mathrm{~m})$ receptor or LDL receptor related-protein (LRP). It has been suggested that this molecular association signals for engulfment of apoptotic cells, through the transmembrane domain of CD91 phagocyte receptor. Furthermore, the phagocytic process occurs with the concomitant uptake of extracellular fluid originating spacious vacuoles, characterizing itself as macropinocytosis (Ogden et al. 2001). The C1q molecule has also been described to play an adjuvant role in apoptotic cell clearance along with another serum protein, the $\mathrm{C}$-reactive protein (CRP); it has been suggested that, in the presence of C1q, CRP binds to lysophospholipids on apoptotic cells and promotes an anti-inflammatory cytokine response. Once necrosis occurs, or in the absence of C1q, elevated serum CRP fails to opsonize and protect apoptotic cells from lysis (Gershov et al. 2000). More recently, CRP has been proposed to be part of an innate immune response to the phosphorylcholine motifs, exposed on apoptotic cells as a result of phospholipid hydrolysis by phospholipase $\mathrm{A}_{2}$ and further oxidation; the authors (Chang et al. 2002) suggested that the phosphorylcholine motif is a cryptic epitope on viable cells and becomes available for CRP binding, after disturbance of surface molecular organization.

The defense collagens can thus function as opsonins to apoptotic cell recognition by phagocytes. Beyond the described roles for the C1q, MBL and SP-D molecules, others have to be considered as contributors to the redundancy of the system (reviewed by Fishelson et al. 2001). Verbovetski et al. (2002) showed that opsonization of apoptotic Jurkat $\mathrm{T}$ cells by autologous iC $3 \mathrm{~b}$ increased significantly their clearance by immature dendritic cells. To date, little is known about complement activating molecules on apoptotic cells or acceptors onto which activated complement components are deposited. PS exposure has been associated to complement activation and $\mathrm{iC} 3 \mathrm{~b}$ deposition on apoptotic cells (Mevorach et al. 1998, Mevorach 2000). In- deed both molecules are distributed in patches on the dying cell surface, although they do not seem to co-localize. CR3/CD11b-CD18/Mac-1 and CR4/CD11c-CD18/ $\beta_{2}$ integrin glycoproteins have been described as receptors for phagocytosis after efficient opsonization of apoptotic cells by $\mathrm{iC} 3 \mathrm{~b}$ (Ross 2000).

The most well characterized system of apoptotic cell recognition is the interaction between externalized phosphatidylserine phospholipid (PS) and its specific recognition molecules, present on the phagocyte surface. PS was first characterized as an "eat-me-signal" on the surface of apoptotic lymphocytes (Fadok et al. 1992). Since then, the importance of PS recognition has been shown in several in vitro and in vivo systems. The milk fat globuleEGF-factor 8 glycoprotein (MFG-E8), secreted by thioglycollate-elicited peritoneal macrophages, binds to apoptotic cells and tethers them to phagocytes for engulfment via the vitronectin integrin receptor. In this situation MFG-E8 carrying a point mutation in the RGD motif inhibits the phagocytosis of apoptotic cells in vitro and in vivo (Hanayama et al. 2002). The 50-kDa serum $\beta_{2}$-glycoprotein I ( $\beta_{2}$ GPI) also intermediates apoptotic cell and phagocyte interaction through PS recognition; antibodies to putative macrophage PS receptors (CD36, CD68, and CD14) were unable to inhibit target cell uptake, suggesting the involvement of a still uncharacterized receptor molecule (Balasubramanian and Schroit 1998). Another serum bridging protein that can stimulate apoptotic cell phagocytosis is the protein $\mathrm{S}$, a vitamin $\mathrm{K}$-dependent plasma protein that has been known for its anticoagulant activity. I It has been described as a bifunctional protein, since its binding property to anionic phospholipids allows it to form complexes with activated protein $\mathrm{C}$. This protein complex inactivates coagulation factors Va and VIIIa (Dahlback 2000), and binds in a calciumdependent manner to the externalized PS on the surface of apoptotic cells (Anderson et al. 2003). The suggestion that the product of a growth arrest specific gene (Gas6) may play a role in the recognition of cells exposing PS on their surfaces by phagocytic 
cells (Nakano et al. 1997) was made almost immediately after its identification as a ligand for the Mer receptor tyrosine kinase (Chen et al. 1997). The same authors were able to show that the uptake of PS liposomes and of apoptotic cells by macrophages was enhanced in approximately twofold in the presence of the Gas6 bridging molecule (Ishimoto et al. 2000). The only described direct interaction between PS and the phagocyte implicates a specific receptor molecule (PSR), present on the surface of different cell types (Fadok et al. 2000). PS/PSR is a low affinity interaction which may justify the aggregated distribution of PS on apoptotic cell surface prior to its recognition and engulfment (Henson et al. 2001). The fact that only aggregated PS/PSR interaction can trigger a functional response in the phagocyte explains the failure of macrophage recognition of PS evenly distributed on the surface of nonapoptotic cells. In addition, a two-step mechanism for the internalization of apoptotic cells by phagocytes has been described: first, the apoptotic cells are tethered to phagocyte surface by different membrane receptors, including CD36, $\alpha \mathrm{v} \beta 3$ and $\alpha \mathrm{v} \beta 5$ integrins, CD14 and CD68 and then PS/PSR interaction promotes their uptake by macropinocytosis (Hoffmann et al. 2001, Somersan and Bhardwaj 2001). This can prevent some inadvertent uptake of many cell types that can transiently expose PS on their external surfaces (Henson et al. 2001). It has been proposed that distinct receptor complexes for PS recognition exist on phagocytes to warrant recognition of the different signals displayed by dying cells, during the progression of apoptotic cell death (Pradhan et al. 1997). Unexpectedly, PS exposure has also been reported to occur on the external surface of phagocytes. Although pre-treatment of macrophages with Annexin V inhibited apoptotic lymphocytes uptake, it is still not clear if PS plays the same role when exposed on the outer leaflets of dying cells and/or phagocytes (Callahan et al. 2000).

The molecular and biochemical mechanisms involved in PS exposure by apoptotic cells are just beginning to be elucidated, but changes on the activity of phospholipids transporters has been re- ported (Daleke 2003). The transbilayer distribution of membrane phospolipids is asymmetric, with the choline-containing ones (phosphatodylcholine (PC) and sphingomyelin (SM)) preferentially exposed on its external surface, and the amine-containing ones (phosphatidylethanolamine (PE) and PS) on the cytoplasmic leaflet. Loss of transmembrane phospholipid asymmetry may occur in both normal and pathological conditions, including activation of blood clotting factors (Chiu et al. 1981) and cell death by apoptosis. PS exposure is induced by the activation of scramblase transporters, which enhances bidirectional lipid transport across plasma membrane and is externally maintained as a consequence of the inhibition of ATP-dependent flipase aminophospholipid translocases, which normally brings PS back to the inner membrane (Fadok et al. 1998, Daleke and Lyles 2000). It has been suggested that, due to its accumulation in the plasma membrane lipid rafts (Sun et al. 2002), the phospholipid scramblase 1 (PLSCR1) may play a role in apoptotic cell signaling in addition to its role in membrane lipid distribution (Daleke 2003). The involvement of floppase aminophospholipid translocases has also been related to PS exposure, emphasizing the role of the adenosine triphosphate (ATP)binding cassette protein 1 (ABC A1) on the engulfment of apoptotic cell corpses from C. elegans (Luciani and Chimini 1996). Another pathway that may be additionally important for the modulation of PS exposure on apoptotic cells is the polyamine metabolism. It is well known that polyamines are essential for cell survival and proliferation and the decrease of their intracellular levels correlates with apoptosis (Nitta et al. 2002). Polyamines can also modulate PS exposure in tumor cells lines (Bratton et al. 1999, Fadok et al. 2001) as well as apoptotic tumor cell fate when recognized by intra-tumoral macrophages (Mills et al. 1992).

Annexin I, has been recently recognized as a coadjuvant in apoptotic cell recognition and engulfment by phagocytes (Arur et al. 2003). After antiFas antibody treatment, Jurkat cells showed first the sequestration of cytosolic Annexin I to the PS-rich 
inner leaflet of the plasma membrane and then PS translocation occurred, with its gradual appearance as discrete patches on the external cell surface. The translocation of Annexin I requires caspase activation and elevation of intracellular calcium levels. It is important to mention that the above cited ABC A1 floppase transporter has been related to the surface exposure of Annexin I on pituitary folliculo-stellate cells (Chapman et al. 2003). Furthermore, the authors implicated the functional role of Annexin I and PSR in the same pathway for apoptotic cell engulfment. Three possibilities were suggested for PS, Annexin I and PSR interaction: first, Annexin I could somehow modify PS structure for PSR recognition, second, both ligand molecules could be recognized as a complex by PSR and finally Annexin I could act as a bridging molecule between PS and PSR (Fadok and Henson 2003). Anyway, these very exciting data open new insights and perspectives on the role of Annexin I in apoptotic cell engulfment and on its putative contribution to the generation of antiinflammatory signals in phagocytes.

The scavenger receptors (SRs) were described in the context of lipoprotein metabolism, but can be distinguish from other lipoprotein receptors by their broad ligand binding properties (Platt et al. 1998). They bind to a wide range of anionic ligands and, as a consequence, have been implicated in functioning as pattern-recognition molecule in host defense and innate immunity and in the clearance of apoptotic cells (Pearson 1996, Platt et al. 1998, Peiser et al. 2002). The oxidation and/or glycosylation of membrane proteins, as well as the surface exposure of anionic phospholipids such as PS, can generate ligands for SRs. Six major classes of SRs were characterized, according to their sequences and properties of the predicted proteins. The Class B CD36 SR was the first one to be demonstrated to play a role in apoptotic cell engulfment, after being transfected into a vitronectin-expressing phagocytically deficient cell (Ren et al. 1995). Indeed CD36 has been described as a required accessory molecule for the functional activity of some of the phagocyte receptors and/or apoptotic bridg- ing molecules (Fadok et al. 1998); the cooperation between the vitronectin receptor $(\mathrm{VnR})$ and thrombospondin 1 (TSP1) bridging molecule in phagocyte recognition of apoptotic neutrophils was found to be CD36-dependent in some systems (Savill et al. 1992) but not in others (Hughes et al. 1997). These data suggests that it is the phagocyte rather than the lineage of the apoptotic cell which defines at least in vitro, which recognition mechanism will be employed in dying cell clearance. On the other hand, apoptotic cell ligands for TSP1 have not been yet characterized. CD36 can also recognize oxidized sites on apoptotic cells that mimic oxidized low-density lipoproteins (oxLDL), in the same way that others SRs do, like the Class E LOX-1 (oxidized low-density lipoprotein receptor 1), the human homologue CD68 and the Class A SRs (Sambrano and Steinberg 1995, Ramprasad et al. 1996, Platt et al. 1996). It has been suggested that the SRs family can act sinergistically or alternatively for the in vivo phagocytic activity, since the frequency of apoptotic thymocytes in SR-A deficient mice is not different than in control animals (Platt et al. 2000).

The glycosylphosphatidylinositol-linked plasma-membrane glycoprotein CD14 is a multifunctional receptor, first known to act in the response to LPS (Ferrero et al. 1993). In this situation and in the presence of the LPS-binding protein (LBP), it associates to the toll-like receptor 4 and its accessory protein MD-2 (TLR4/MD-2 complex) and triggers an inflammatory cytokine production by phagocytes (Jiang et al. 2000, Viriyakosol et al. 2001). In a complementary way, CD14 has been described to bind specifically to minimally modified low density lipoproteins (mmLDL), originated from the mild oxidation of LDL, inhibiting apoptotic cell uptake and triggering TLR4/MD-2 signaling and macrophage spreading (Miller et al. 2003). But the multifunctionality of CD14 is underscored by its role in apoptotic cell clearance when it induces an opposite macrophage response (Devitt et al. 1998, Gregory 2000). In spite of binding to phospholipids, including PS (Wang et al. 1998), it seems unlikely that CD14 can function as a PS receptor, at least when 
judged by in vitro assays of the engulfment ability of inactivated macrophages (Devitt et al. 2003). By contrast, a putative candidate for CD14 recognition on apoptotic cell surface is the highly glycosylated Ig-superfamily member, the Intercellular adhesion molecule 3 (ICAM-3), constitutively expressed on leukocytes (Fawcett et al. 1992). It was demonstrated that, when induced to undergo apoptosis, leukocytes display altered ICAM-3 molecules so that they become able to be recognized by CD14 and cleared by phagocytes. However it seems that the role of CD14 in dying cell clearance is not limited to its interaction with the adhesion molecule ICAM3 , since it also functions in the clearance of ICAM-3 negative apoptotic cells (Moffatt et al. 1999).

A recent work on other adhesion molecule, made by Brown et al. (2002), showed us that phagocytes can not only recognize "eat-me" signals on dying cells surface, but also a "leave-me-away" signal, displayed by living cells. This property has been attributed to the surface protein CD31, also known as platelet endothelial cell adhesion molecule1 (PECAM-1), a member of the Ig gene superfamily normally expressed on the surface of leukocytes, macrophages, platelets and endothelial cells. CD31 plays an important role in vascular cell biology, including its participation in the adhesion cascade leading to extravasation of leukocytes during inflammatory processes (Newman 1997); homophilic interaction between two CD31 molecules can operate as a molecular "handshake" (Chimini 2002) and regulates leukocyte motility and active movement across endothelial cell surfaces. The intracellular signaling triggered on viable target cells probably involves tyrosine phosphorylation of CD31 cytoplasmic tail and further interaction with the protein-tyrosine phosphatases SHP-1 and SHP2 (Jackson et al. 1997, Pumphrey et al. 1999) and somehow "instructs" the phagocyte to let living cells escape the phagocytic process. What has been shown in addition, is that CD31 signaling is disabled in apoptotic cells, promoting their tethering to and engulfment by phagocytes. The interpretation of the detachment signal on living cells may represent an important mechanism to prevent macrophage ingestion of viable self-cells (Brown et al. 2002).

It is relevant to mention that some, if not most, of the molecules described above, as important to allow apoptotic cells/ phagocytes interplay in mammalian systems, were identified from their homology with genes and proteins first characterized in non-mammalian systems, that will be discussed below.

\section{APOPTOTIC CELL RECOGNITION IN NON-MAMMALIAN SYSTEMS}

The evolutionary conservation of the apoptotic machinery among invertebrates and vertebrates allows the use of genetic model systems, like Dictyostelium discoideum, C. elegans and Droshophila melanogaster (D. melanogaster), as powerful tools towards the understanding of apoptotic cell death and clearance in mammals. Three genes act in a cooperative manner to initiate apoptosis regulation in Drosophila embryo, called reaper (rpr), head involution defective (hid) and grim. They have been shown to inhibit one of the three Inhibitors of Apoptosis Proteins (IAPs) found in Drosophila, the dIAP1, thus allowing the activation of five executional caspases and the consequent cell death (Hawkins et al. 1999, Bangs et al. 2000). Exposure of PS has been demonstrated in apoptotic cells present on the proboscis of Drosophila pupa (Eijnde et al. 1998), but the molecules responsible for its recognition are still unknown. Indeed Drosophila is a very informative study model for phagocytosis of apoptotic cells, since approximately $90-95 \%$ of their embryonic blood cells (hemocytes) acquires phagocytic capacity (Tepass et al. 1994) and display similar features to mammalian macrophages (Abrams et al. 1993, White et al. 1994, Franc et al. 1999a). The receptor Croquemort $(\mathrm{Crq})$ is a CD-36 related molecule (Franc et al. 1996) and can be a candidate for PS recognition by Drosophila hemocytes. It is expressed exclusively on embryonic macrophages, where it contributes to the efficiency of apoptotic corpse clearance (Franc et al. 1999b). Whether Crq 
requires other partners to assemble in a phagocytic complex remains to be explored. Two other receptors may play a role in the recognition of apoptotic cells by Drosophila embryo: the PS receptor homologue, which displays considerable homology with the predicted protein sequences found in C. elegans and mammals (Fadok et al. 2000), and the scavenger receptor DSR-C1 (Pearson et al. 1995).

In $C$. elegans, there is still a black box between the activation of caspases (four of them have been identified until now - CED-3, CED-9, CED-4 and CED-7), and the displaying of "eat-me"' signals by the dying cells. CED-3 (caspase 3 homologue) and CED-4 (Apaf-1 homologue) are executioner caspases, which activities can be inhibited by CED-9 (BCL-2 homologue). The caspases seem not to be entirely responsible for apoptosis triggering, since nematodes with inactivated CED-3 still have very low levels of cells death (Gumienny et al. 1999). It has been suggested that CED-7 can participate in PS exposure and recognition in worms (Gumienny and Hengartner 2001), due to its homology with the aminophospholipid translocase ABC1, which promotes PS exposure in mammals (Hamon et al. 2000). Differently from what is observed in Drosophila, the clearance of dying cells in C. elegans (Gumienny and Hengartner 2001), as well as in Dictyostelium discoideum (Arnoult et al. 2001), is performed by non specialized neighboring cells. Only a few reports have been made on phagocytosis of dying cells in the D. discoideum (Arnoult et al. 2001), the more recent being the involvement of the adaptor complex-1 (AP-1), normally participating in the budding of clathrin-coated vesicles from the trans-Golgi network and endosomes (Lefkir et al. 2003); the authors generated Dictyostelium mutant cells, disrupted for AP-1 medium chain, and found impaired phagocytosis, mainly for large particles. There are no evidences, until now, of circulating molecules important for the process of engulfment in C. elegans. The putative receptor displayed by the engulfing cell is the transmembrane molecule CED1 , with some similarity to the scavenger receptor expressed by endothelial cells, SREC (Zhou et al. 2001a, Adachi et al. 1997). The predicted protein sequence F29B9.4 (Fadok et al. 2000) had just been identified as the open reading frame of the C.elegans PSR homolog, the PSR-1 (Wang et al. 2003). The intracellular signaling triggered on the engulfing cells, by their recognition of non-mammalian dying cells, will be discussed in the next section, since the molecules and pathways involved are equivalent to the ones described for mammalian systems.

\section{THE MEANING OF CELL DEATH: FUNCTIONAL CONSEQUENCES OF APOPTOTIC CELL SIGNALING AND OF ENGULFMENT BY PHAGOCYTES}

Several hallmarks of apoptosis have been described in the last years (reviewed by Geske and Gerchenson 2001), but some of them - caspase activation, loss of mitochondrial membrane potential or PS exposure - are not specific in that they can also be observed in viable cells and in various degrees of necrotic cell death. Thus one must consider a range of techniques to reach the diagnosis of in vitro apoptosis and the observation of cell morphology at the electron-microscope level still remains as the best parameter to be observed. But the most relevant matter to consider relates to the in vivo diagnosis of apoptosis. The crucial feature to be analyzed in vivo is the capacity of the dying cell or apoptotic bodies to be recognized and engulfed by phagocytes, with still intact membranes (Savill et al. 2002). Therefore it is the efficiency of apoptotic cell signaling, recognition and uptake that will define the actual meaning of cell death.

The intracellular signaling triggered by apoptotic cells for their engulfment by mammalian phagocytes is not completely understood, but some advances have occurred in recent years, the majority of them arising from discoveries made in the nematode Caenorhabditis elegans (Ellis et al. 1991, Horvitz 1999, Hengartner 2001, Gumienny and Hengartner 2001). Seven genes involved in the dying cell recognition by the engulfing cell have been cloned, further allowing the search for mammalian 
homologues. Worm mutants for any of these genes showed non engulfed cell corpses remaining for hours or even days. Double mutant studies in the worm have resulted in the isolation of several mutations that affect engulfment and the severity of their phenotypic consequences defined two pathways for phagocytosis of dying cells (Gumienny and Hengartner 2001).

One group of genes includes ced-2, ced-5, ced10 and ced-12 (standing for Cell Death abnormal genes), defined as members of the Rac1 GTPase pathway (Wu and Horvitz 1998a, Chung et al. 2000, Reddien and Horvitz 2000). Their mammalian counterparts are, respectively, the small adaptor protein CrkII (Kiyokawa et al. 1997), its interactive neighbor Dock180 (Hasegawa et al. 1996), the Rholike GTPase Rac1 (Van Aelst and D'Souza Schorey 1997) and ELMO1 and ELMO2 (Gumienny et al. 2001). The observed homology at protein level between these molecules is corroborated by the strict correspondence of their roles on the modulation of phagocytosis in worms and mammals (Figure 2). The CED-2/CrkII protein is composed of three Srchomology domains (one SH2 and two SH3) and CED-5/Dock180 binds to the first SH3 domain of CrkII (Hasegawa et al. 1996). It has been recently shown that the evolutionary conserved CED-12/ ELMO protein physically interacts with CED5/Dock180, forming a ternary complex with CED2/CrkII (Zhou et al. 2001b, Wu et al. 2001), that in turn stimulates a Rac-GEF activity (standing for Guanine nucleotide Exchange Factor) (Gumienny et al. 2001). The activity of Rho GTPases cycles between an inactive GDP-bound state and an active GTP-bound state and the GEFs enhance the exchange of bound GDP for GTP. Brugnera et al. (2002) identified a specific domain within CED5/Dock180 (denoted Docker), able to mediate GTP loading of CED-10/Rac1 in vitro; since the binding of Dock180 to Rac1 was dependent of Dock180ELMO1 interaction, the authors proposed that this dimeric complex functions as an exchange factor (GEF) for CED-10/Rac1. Rac1 activation leads to cytoskeletal rearrangements and affects engulfment and cell migration from worms to mammals (Gumienny et al. 2001). What happens between the recognition of apoptotic cells by specific phagocyte receptors and the recruitment and activation of the cytoplasmic molecular complexes described above is still a black box. On the other hand, we already know some of the phagocyte receptors that function upstream of this black box. It has been suggested that the mammalian PSR (Fadok et al. 2000) recruits the CED-5/Dock180 - CED-2/CrkII - CED-12/ELMO protein complex before CED-10/Rac1 activation, increasing apoptotic cell uptake by phagocytes (S. Gardai and P.M. Henson, personal communication). Indeed, this is the operating pathway in C. elegans engulfing cells after PSR-1 triggering (Wang et al. 2003). The $\alpha_{\mathrm{V}} \beta_{5}$ integrin present on the surface membrane of a human epithelial cell line, is endowed with the ability to capture apoptotic cells in a manner akin to that of dendritic cells; additionally the integrin heterodimer uses a tyrosinekinase signaling pathway to recruit the tyrosinephosphorylated p130 cas - CrkII - Dock180 complex and trigger Rac1 activation and phagosome formation (Birge et al. 1992, Albert et al. 2000).

The second group of evolutionary conserved genes important for dying cell phagocytosis includes ced-6/gulp, ced-1/CD91 and ced-7/abcl (Liu and Hengartner 1998, 1999, Zhou et al. 2001a, Wu and Horvitz 1998b). The CED-1 protein has been identified as a transmembrane receptor that mediates dying cells uptake in C. elegans (Zhou et al. 2001a), similarly to the functional role played by CD91/LRP (Low density lipoprotein Receptor-related Protein) in mammals. Indeed CED-1 and CD91 were characterized as homologue proteins based on the comparison of their functional motifs. Both receptor proteins bind to the phosphotyrosine domain of the adaptor protein CED-6/GULP (from engulfment adaptor protein); in the case of CED-1, the specific motif NPXY, present in its cytoplasmic tail, has been implicated ( $\mathrm{Su}$ et al. 2002). The CED-7 protein displays sequence similarity with $\mathrm{ABC}$ transporters and functions in both dying cells and engulfing cells during the uptake process in C. elegans (Wu and 


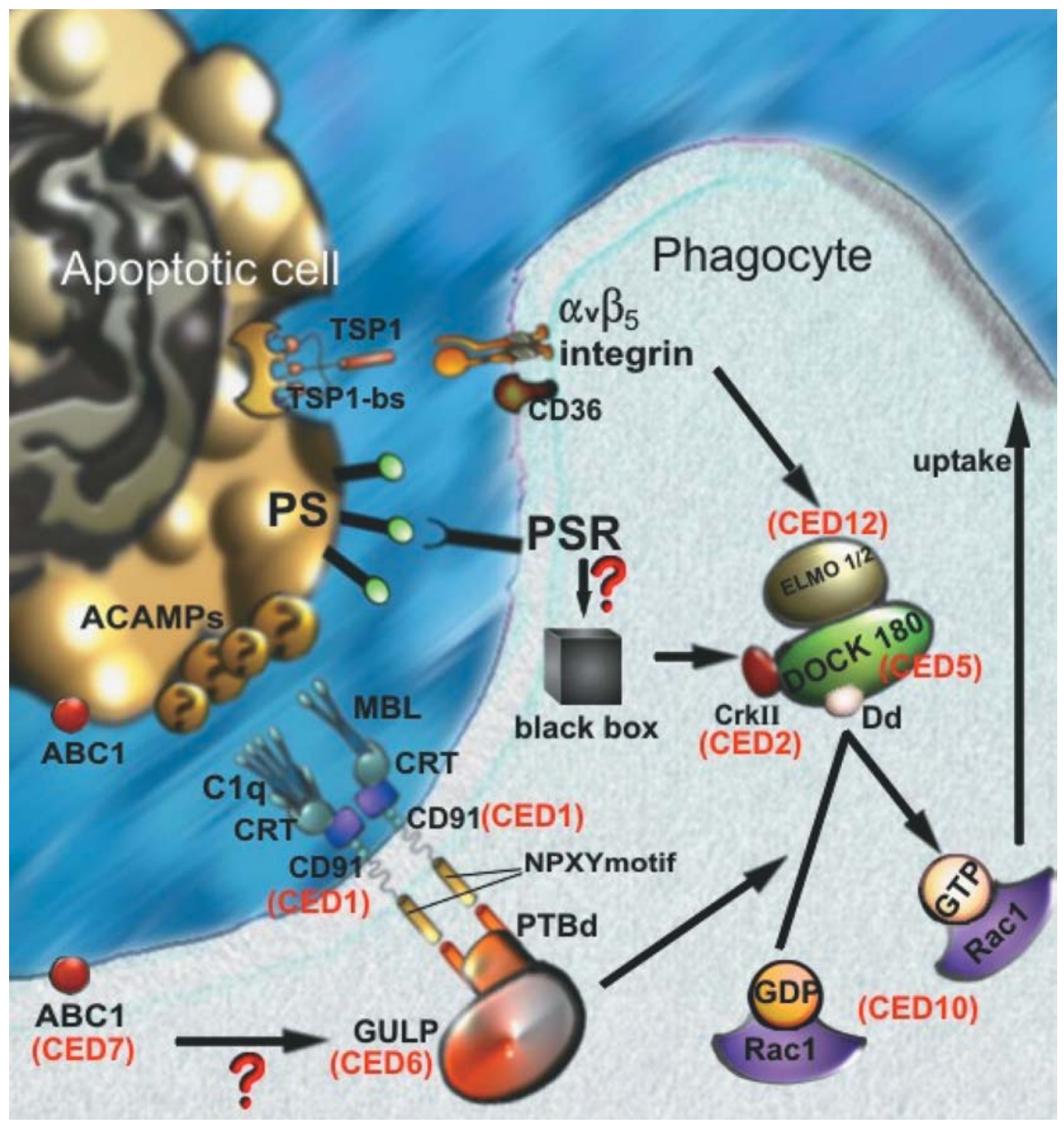

Fig. 2 - Ligands and receptors involved in the ELMO/DOCK180/CrkII pathway. Still unidentified apoptotic cell associated molecular patterns (ACAMPs) are recognized by $\mathrm{C} 1 \mathrm{q}$ and $\mathrm{MBL}$ collectins, that in turn bind to calreticulin and transmenbrane protein CD91. Following the interaction between CD91 cytoplasmic tail and the enGULfment adaPtor protein (GULP), the ternary complex ELMO/DOCK180/CrkII is recruited, as well as after the activation $\alpha_{v} \beta_{5}$ integrin. $\mathrm{ABC} 1$ and PS receptor molecules seem also to be engaged in the proteic complex activation, which converts inactive GDP bound-Rac1 in its active form (GTP bound-Rac1). Activation of the Rho-like GTPase Rac1 leads to cytoskeletal rearrangements and increased engulfment from worms to mammals. The homologue proteins characterized in worms are shown in brackets. See details in the text.

Horvitz 1998b). It has been observed that ced-7 defective mutants fail to show CED-1 membrane clustering around neighboring cell corpses, suggesting a role for CED-7 protein in dying cell recognition by CED-1 (Zhou et al. 2001a). It seems that both CED-1/CD91 and CED-7/ABC1 can activate Rac1 after interaction with CED-6/GULP, but this matter still needs further studies to be clarified. 
The phagocyte receptors described above, as well as the intracellular signaling pathways triggered after their recognition of target cells, were characterized in macrophages and also in epithelial cell lines (Savill et al. 2002, Albert et al. 2000). There are only a few descriptions of the receptor molecules used by dendritic cells (DCs) to interact with apoptotic cells, and these relate mainly to a protein of the integrin family. The participation of the $\alpha_{\mathrm{V}} \beta_{5}$ integrin receptor in apoptotic cell engulfment distinguishes DCs (Albert et al. 1998a) from macrophages, which lack this integrin molecule and use the vitronectin receptor $\alpha_{\mathrm{V}} \beta_{3}$ to the same end (Albert et al. 1998b). On the other hand, the $\alpha_{\mathrm{V}} \beta_{3}$ integrin heterodimer has been suggested to also mediate apoptotic cell uptake by immature DCs (Rubartelli et al. 1997), which may reflect the existence of cell subpopulations using different integrin receptors (Nouri Shirazi et al. 2000). DCs not only internalize the apoptotic material but also generate peptide epitopes for presentation by MHC I and MHC II molecules (Albert et al. 1998a, Inaba et al. 1998). These data led to a very important aspect of investigation, towards the understanding of the differential behavior of both professional phagocytes in the face of apoptotic material (Green and Beere 2000). Apoptotic cell clearance by macrophages has been related to anti-inflammatory and immunosuppressive responses (Voll et al. 1997, Savill and Fadok 2000, Savill et al. 2002), although they can produce pro-inflammatory mediators in transient experimental conditions (Kurosaka et al. 2001). It is clear that in vivo, inflammation does not persists in tissue in which cell turnover is high; two mechanisms have been described to explain this fact (Geske et al. 2002). One is the removal by macrophages of late apoptotic and/or secondary necrotic cells, which carry potentially harmful intracellular contents, without causing an inflammatory response (Ren et al. 2001, Fadok et al. 2001). The other i is the increase on the release of anti-inflammatory mediators, such as interleukin-10 (IL-10) (Voll et al. 1997) and TGF- $\beta_{1}$ (Fadok et al. 1998, McDonald et al. 1999). In addition, it has been suggested that the amount of TGF- $\beta_{1}$ produced by murine peritoneal macrophages correlates with the levels of PS receptor (PSR) on the phagocyte surface, since thioglycollate-elicited macrophages stain strongly for the receptor molecule and produce 5 times more TGF- $\beta_{1}$ than the resident ones, which display low levels of PSR (Geske et al. 2002). Phagocyte receptors, others than PSR, can actually be involved in TGF- $\beta_{1}$ releasing by macrophages and in their autocrine anti-inflammatory suppression, like CD36 and $\alpha_{\mathrm{V}} \beta_{3}$ integrin (Voll et al. 1997, Freire de Lima et al. 2000).

Dendritic cells loading with apoptotic cells was first associated with the triggering of inflammatory responses (Albert et al. 1998a). Soon after, the same group gave more light to this matter, when they showed that only immature DCs have the ability to phagocytose apoptotic cells, via the $\alpha_{\mathrm{V}} \beta_{5}$ and CD36 receptors (Albert et al. 1998b); in this stage of development, DCs express low levels of MHC and costimulatory molecules needed for $\mathrm{T}$ cell stimulation (Banchereau and Steinman 1998). After apoptotic cell uptake, if exposed to maturation signals (Sauter et al. 2000) and to CD4 ${ }^{+} \mathrm{T}$ helper cells, DCs are able to cross-prime antigen-specific $\mathrm{CD}^{+} \mathrm{T}$ cells, which produce IFN- $\gamma$ and develop into effector cytotoxic T lymphocytes (CTLs). On the other hand, DCs also mediate $T$ cell tolerance in the absence of $\mathrm{CD}^{+} \mathrm{T}$ cells: in this situation even mature DCs do not do cross-prime, but instead they recognize apoptotic cell via $\mathrm{CD} 40$ and further mediate $\mathrm{CD} 8^{+} \mathrm{T}$ cells tolerization (Albert et al. 2001). Thus it is clear that there exists, in different situations, a balance between signals from the anti- and pro-inflammatory receptors; Fadok et al. (1998) have some evidence to suggest that signaling through the immunoglobulin Fc receptor in macrophages can override signaling via the PSR, that in turn appears to override that derived from the Toll-like receptor 4 (TLR4) (Geske et al. 2002). The hierarchy of responses to apoptotic cell recognition seems to be determined by each type of cellular interaction, as well as by the microenvironment, when different phagocyte receptors or combination of receptors will be triggered. 


\section{APOPTOTIC MIMICRY: UNCOUPLING PS EXPOSURE AND RECOGNITION FROM CELL DEATH}

The molecular machinery involved in programmed cell death has now been investigated in four phylogenetic branches of metazoans (cnidaria, nematodes, insects and mammals) and also in four groups of unicellular eukaryotes (protozoans parasites, flagellates, yeasts and the slime mold Dictyostelium discoideum) (Williams and Smith 1993, DosReis and Barcinski 2001, Arnoult et al. 2002, Al Olayan et al. 2002, see Ameisen 2002 for a complete review). It is however not yet established what purposes PCD serves on all those different species. Indeed, PS exposure has been observed in several unicellular organisms (Table I), but only in the case of the protozoan parasite Leishmania amazonensis (L. amazonensis), it has been related to recognition, signaling and inhibition of microbicidal activity of host cells (De Freitas Balanco, Moreira et al. 2001). As a matter of fact, Leishmania spp is the only microorganism included in Table I that is an obligatory intramacrophagic parasite. Indeed almost 20 years ago Gilbreath et al. (1985) observed that lipid molecules could somehow downregulate macrophage effector function against Leishmania major amastigotes. We have shown that the antiPSR specific monoclonal antibody (previously described by Fadok et al. 2000 and kindly donated to us) actually inhibits the interaction between the amastigote form of L. amazonensis and its only host cell within vertebrates, the macrophage; the majority of amastigote population displays PS on the outer leaflet of its plasma membrane and the consequences of signaling by this phospholipid are exacerbation of infection and upregulation of the production by infected macrophages of anti-inflammatory cytokines such as TGF- $\beta_{1}$ and IL-10 (Balanco, Moreira et al. 2001). When maintained in axenic in vitro cultures, lesion-derived amastigotes display oligonucleossomal DNA degradation while their plasma membrane remains intact (Figure 3). Since this parasite survives when inside the cell, these data suggest that a) Leishmania amastigotes possesses the PCD machin- ery and b) host macrophages have the potential for rescuing parasites from apoptotic cell death. Leishmania promastigotes have been also shown to display PS exposure, loss of mitochondrial transmembrane potential loss, cytochrome $\mathrm{C}$ release, caspase3-like activity, oligonucleossomal DNA degradation and nuclear chromatin condensation and fragmentation (Moreira et al. 1996, De Freitas Balanco et al. unpublished data, Arnoult et al. 2002). These findings implicate in the evolutionary conservation of components of the apoptotic machinery and of apoptotic cell recognition between unicellular and multicellular organisms. The importance of PS recognition to the establishment of parasitic diseases has been recently corroborated by the characterization of a specific interaction between the lysophosphatidylserine (lyso-PS) present in the worm Schistosoma mansoni and the Toll-like receptor 2 (TLR2) on mammalian host DCs; the $S$. mansoni lyso-PS triggers DCs maturation via TLR2, resulting in the development of IL-10-producing regulatory $\mathrm{T}$ cells (Van der Kleij et al. 2002).

It is also well known that significant amount of apoptotic tumor cells can be found in growing tumor sites and that their presence can dramatically increase tumor transfer efficiency (Kornbluth et al. 1994). Since tumor cell destruction induced by most current cancer treatment regimes predominantly results in tumor cell apoptosis, surviving cells, instead of being recognized and eliminated by surrounding phagocytes, they accumulate as the malignant process proceeds. Malignant transformation is a dynamic process, involving cells resistant and susceptible to apoptosis, as well as phagocytic cells, being the latter of tumor and/or non-tumor origins. Tumoricidal phagocytes are supposed to undergo a kind of maturation process, in order to be able to recognize and discriminate transformed (apoptotic and non-apoptotic) from non-transformed cells and efficiently clear the first ones without damaging normal surrounding cells, probably using different recognition patterns. Unfortunately, they are not always successful performing this task and indeed, on the contrary, there are several situations in which 
TABLE I

Phosphatidylserine exposure in the plasma membrane outer leaflet of single-celled eukaryotes.

\begin{tabular}{l|l|l}
\hline Species & Inducing agent & Reference \\
\hline Peridinium gatunense & $\mathrm{CO}_{2}$ depletion / ROS & Vardi et al. 1999 \\
\hline Blastocystis hominis & $\begin{array}{l}\text { Cytotoxic antibody } \\
\text { mAb (1D5) }\end{array}$ & Nasirudeen et al. 2001 \\
\hline Dictyostelium discoideum & starvation & $\begin{array}{l}\text { Arnoult et al. 2001 } \\
\text { Tatischeff et al. 2001 }\end{array}$ \\
\hline Leishmania amazonensis & none & De Freitas Balanco, Moreira et al. 2001 \\
\hline Leishmania major & staurosporine & Arnoult et al. 2002 \\
\hline Plasmodium berghei & none (cell suicide) & Al Olayan et al. 2002 \\
\hline Trichomonas vaginalis & staurosporine & Chose et al. 2002 \\
\hline
\end{tabular}

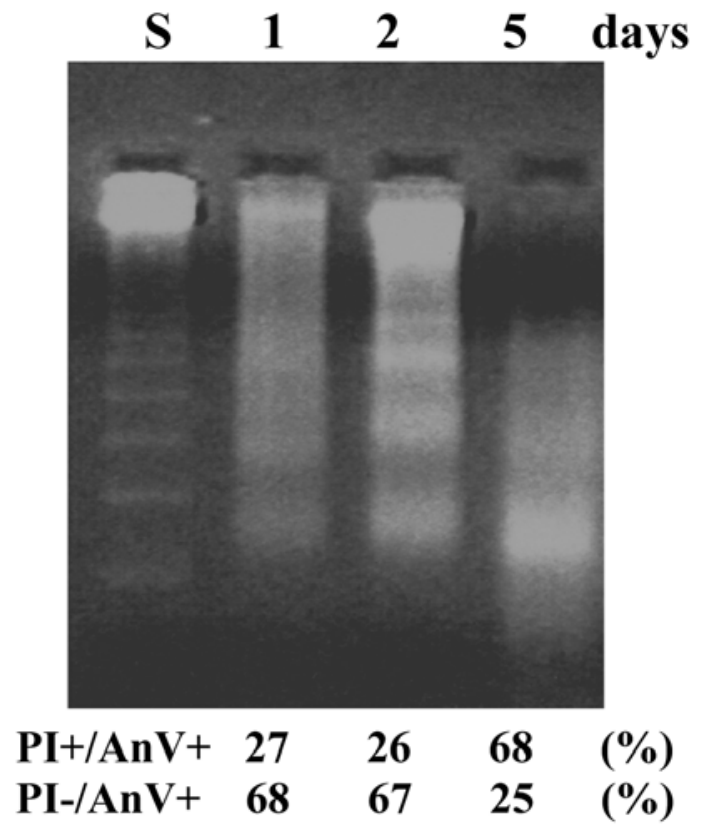

Fig. 3 - DNA analysis of Leishmania (L) amazonensis amastigotes. Parasites were purified from Balb/c mice footpad lesions and incubated axenically for 1,2 or 5 days at $34^{\circ} \mathrm{C}$. After the in vitro culture, the parasite samples were incubated for 15 minutes with or without $0.5 \mu \mathrm{g} / \mathrm{ml}$ Annexin V-FITC (AnV) and $0.7 \mu \mathrm{g} / \mathrm{ml}$ propidium iodide (PI) and analysed by flow cytometry (FACScan, Becton and Dickinson). DNA were extracted from the incubated parasites and analysed by electrophoresis in a $1.8 \% \%$ agarose gel. S: molecular size standard: 123bp ladder (Invitrogen). macrophages even support tumor growth and angiogenesis (Crowther et al. 2001, Bingle et al. 2002), displaying suppression of inflammatory responses (Reiter et al. 1999, Fadok et al. 2000) and producing increased amounts of non-inflammatory cytokines (Fadok et al. 2000, Hoffmann et al. 2001, Voll et al. 1997).

As well as the mentioned parasites, tumor cells certainly display different and efficient mechanisms of escaping from innate immune response and we can suggest that apoptotic tumor cells and probably PS phospholipids may be important pieces of this game. PS molecules ability to downregulate phagocyte responses is well known (Aramaki 2000); Matsuno et al. (2001) showed that PS-liposomes decrease NO production by macrophages through the induction of TGF- $\beta_{1}$. We have evidences that malignant melanoma cells expose PS when viable and produce high amounts of PS-positive vesicles in vitro and in vivo; furthermore these vesicles play a significant role in tumor establishment in vivo (Lima LG, Geske FJ, Fadok VA and Moreira MEC, unpublished data). Utsugi et al. (1991) have previously shown that malignant melanoma cells fail to regulate plasma membrane phospholipid asymmetry thus exposing PS while still viable. In addition, vesiculation of tumor cells has been related to increased invasiveness (Ginestra et al. 1998, 1999). It 
is also clear that melanoma cells express PSR, can ingest apoptotic cells and can secrete TGF- $\beta_{1}$ in response to apoptotic cells or to triggering PSR with the anti-PSR receptor antibody (Geske FJ and Fadok VA, unpublished data). We can suggest that malignant tumor cells have learned to subvert immune response exploiting, like some unicellular parasites, the PS/PSR interaction and that the process of vesiculation could function as an amplifying mechanism to phagocyte inactivation after PS recognition and signaling.

\section{CONCLUSIONS}

Our take-home message is that the apoptotic cell and phagocyte interplay does not necessarily end with the death of the former; instead, cells, like parasites or tumors, can benefit from apoptotic cell phenotype to inactivate phagocytes and subvert host immune response against them.

We propose that several alterations on target cells surface are phylogenetically conserved, although there may be differences in molecular distribution and/or associations among different cell types. Furthermore, the vast number of receptor molecules, which way-of-action is already well characterized in mammalian phagocytes, may associate differentially or act synergistically to improve the recognition of and signaling from nonmammalian target cells.

In this context, we think that further studies on the evolutionary aspects of PS exposure, recognition and signaling mechanisms will be of extreme importance to clarify the fate of inflammatory, infectious and tumoral processes, the establishment of parasitic infections (Freire de Lima et al. 2000) and the suppression of antitumor local reactions (Reiter et al. 1999).

\section{ACKNOWLEDGMENTS}

We are most grateful to Peter M. Henson for valuable comments and to our undergraduate student Fernando Real (arieviln@godisdead.com), for the creation of the exemplary cartoons depicted on this review.

\section{RESUMO}

A morte celular por apoptose é caracterizada por alterações bioquímicas e moleculares específicas, incluindo a exposição de diversos ligantes, responsáveis pelo seu reconhecimento imediato por fagócitos. Em situações não patológicas, a remoção eficiente da célula apoptótica é assegurada pela redundância do sistema, onde ocorre a interação dos diversos ligantes por ela expostos com as moléculas receptoras presentes na superfície da célula fagocítica. A presente revisão enfatisará as interações moleculares operantes em sistemas celulares de mamíferos e não mamíferos, assim como as consequências do seu reconhecimento e sinalização. Além disso, serão discutidos alguns modelos celulares nos quais a exposição do fosfolipídeo fosfatidilserina (PS), característica do fenótipo apotótico, não é obrigatoriamente seguida da morte celular.

Palavras-chave: morte celular, apoptose, reconhecimento da célula apoptótica, mimetismo apoptótico, fagócito, sinalização intracelular.

\section{REFERENCES}

Abrams JM, White K, Fessler LI and Steller H. 1993. Programmed cell death during Drosophila embryogenesis. Development 117: 29-43.

Adachi H, Tsujimoto M, Arai H and Inoue K. 1997. Expression cloning of a novel scavenger receptor from human endothelial cells. J Biol Chem 272: 31217-31220.

Al Olayan EM, Williams GT and Hurd H. 2002. Apoptosis in the malaria protozoan, Plasmodium berghei: a possible mechanism for limiting intensity of infection in the mosquito. Int $\mathbf{J}$ Parasitol 32: 1133-1143.

Albert ML, Sauter B and Bhardwaj N. 1998a. Dendritic cells acquire antigen from apoptotic cells and induce class I-restricted CTLs. Nature 392: 86-89.

Albert ML, Pearce SF, Francisco LM, Sauter B, Roy P, Silverstein RL and Bhardwaj N. 1998b. Immature dendritic cells phagocytose apoptotic cells via $\alpha_{\mathrm{V}} \beta_{5}$ and $\mathrm{CD} 36$, and cross-present antigens to cytotoxic T lymphocytes. J Exp Med 188: 13591368.

Albert ML, Kim JI and Birge RB. 2000. $\alpha_{\mathrm{V}} \beta_{5}$ integrin recruits the CrkII-Dock180-rac1 complex for phagocytosis of apoptotic cells. Nat Cell Biol 2: 899-905. 
Albert ML, Jegathesan M and Darnell RB. 2001. Dendritic cell maturation is required for the crosstolerization of $\mathrm{CD}^{+} \mathrm{T}$ cells. Nat Immunol 2: 10101017.

Amarante Mendes GP, Finucane DM, Martin SJ, Cotter TG, Salvesen GS ANd Green DR. 1998. Anti-apoptotic oncogenes prevent caspase-dependent and independent commitment for cell death. Cell Death Differ 5: 298-306.

Ameisen JC. 2002. On the origin, evolution, and nature of programmed cell death: a timeline of four billion years. Cell Death Differ 9: 367-393.

Anderson HA, Maylock CA, Williams JA, Paweletz CP, Shu H and Shacter E. 2003. Serum-derived protein $\mathrm{S}$ binds to phosphatidylserine and stimulates the phagocytosis of apoptotic cells. Nat Immunol 4: 87-91.

AramaKi Y. 2000. Liposomes as immunomodulator inhibitory effect of liposomes on NO production from macrophages. Biol Pharm Bull 23: 1267-1274.

Arnoult D, Tatischeff I, Estaquier J, Girard M, Sureau F, Tissier JP, Grodet A, Dellinger M, Traincard F, Kahn A, Ameisen JC and PeTIT PX. 2001. On the evolutionary conservation of the cell death pathway: mitochondrial release of an apoptosis-inducing factor during Dictyostelium discoideum cell death. Mol Biol Cell 12: 3016-3030.

Arnoult D, Akarid K, Grodet A, Petit PX, EsTAQUIER J AND AMEISEN JC. 2002. On the evolution of programmed cell death: apoptosis of the unicellular eukaryote Leishmania major involves cysteine proteinase activation and mitochondrion permeabilization. Cell Death Differ 9: 65-81.

Aruffo A, Stamenkovic I, Melnick M, Underhill CB AND SEED B. 1990. CD44 is the principal cell surface receptor for hyaluronate. Cell 61: 1303-1313.

Arur S, Uche UE, Rezaul K, Fong M, Scranton V, Cowan AE, Mohler W and Han DK. 2003. Annexin $\mathrm{I}$ is an endogenous ligand that mediates apoptotic cell engulfment. Dev Cell 4: 587-598.

Balasubramanian K and Schroit AJ. 1998. Characterization of phosphatidylserine-dependent $\beta_{2}$ glycoprotein I macrophage interactions. Implications for apoptotic cell clearance by phagocytes. J Biol Chem 273: 29272-29277.
Banchereau J and Steinman RM. 1998. Dendritic cells and the control of immunity. Nature 392: 245-252.

Bangs P, Franc N and White K. 2000. Molecular mechanisms of cell death and phagocytosis in Drosophila. Cell Death Differ 7: 1027-1034.

Bingle L, Brown NJ And Lewis CE. 2002. The role of tumour-associated macrophages in tumour progression: implications for new anticancer therapies. J Pathol 196: 254-265.

Birge RB, Fajardo JE, Mayer BJ and Hanafusa H. 1992. Tyrosine-phosphorylated epidermal growth factor receptor and cellular p130 provide high affinity binding substrates to analyze Crk-phosphotyrosinedependent interactions in vitro. J Biol Chem 267: 10588-10595.

Botto M, Dell Agnola C, Bygrave AE, Thompson EM, CoOK HT, Petry F, Loos M, PANdolfi PP AND Walport MJ. 1998. Homozygous C1q deficiency causes glomerulonephritis associated with multiple apoptotic bodies. Nat Genet 19: 56-59.

Bratton DL, Fadok VA, Richter DA, Kailey JM, Frasch SC, Nakamura T and Henson PM. 1999. Polyamine regulation of plasma membrane phospholipid flip-flop during apoptosis. J Biol Chem 274: 28113-28120.

Brown S, Heinisch I, Ross E, Shaw K, Buckley CD And Savill J. 2002. Apoptosis disables CD31mediated cell detachment from phagocytes promoting binding and engulfment. Nature 418: 200-203.

Brugnera E, Haney L, Grimsley C, Lu M, Walk SF, Tosello Trampont AC, Macara IG, Madhani H, FINK GR AND RaVICHANDRAN KS. 2002. Unconventional Rac-GEF activity is mediated through the Dock180-ELMO complex. Nat Cell Biol 4: 574-582.

Bursch W. 2001. The autophagosomal-lysosomal compartment in programmed cell death. Cell Death Differ 8: $569-581$.

Callahan MK, Williamson P and Schlegel RA. 2000. Surface expression of phosphatidylserine on macrophages is required for phagocytosis of apoptotic thymocytes. Cell Death Differ 7: 645-653.

Chang MK, Binder CJ, Torzewski and Witztum JL. 2002. C-reactive protein binds to both oxidized LDL and apoptotic cells through recognition of a commom ligand: Phosphorylcholine of oxidized phospholipids. Proc Natl Acad Sci 99: 13043-13048. 
Chapman LP, Epton MJ, Buckingham JC, Morris JF AND Christian HC. 2003. Evidence for a role of the adenosine 5'-triphosphate-binding cassette transporter A1 in the externalization of annexin I from pituitary folliculo-stellate cells. Endocrinology 144: 1062-1073.

Chen J, Carey K and Godowski PJ. 1997. Identification of Gas6 as a ligand for Mer, a neural cell adhesion molecule related receptor tyrosine kinase implicated in cellular transformation. Oncogene 14: 2033-2039.

Chimini G. 2002. Apoptosis: repulsive encounters. Nature 418: 139-141.

Chiu D, Lubin B, Roelofsen B and van Deenen LL. 1981. Sickled erythrocytes accelerate clotting in vitro: an effect of abnormal membrane lipid asymmetry. Blood 58: 398-401.

Chose O, Noel C, Gerbod D, Brenner C, Viscogliosi E AND Roseto A. 2002. A form of cell death with some features resembling apoptosis in the amitochondrial unicellular organism Trichomonas vaginalis. Exp Cell Res 276: 32-39.

Chung CY, Lee S, Briscoe C, Ellsworth C and FirTEL RA. 2000. Role of Rac in controlling the actin cytoskeleton and chemotaxis in motile cells. Proc Natl Acad Sci USA 97: 5225-5230.

Crowther M, Brown NJ, Bishop ET and Lewis CE. 2001. Microenvironmental influence on macrophage regulation of angiogenesis in wounds and malignant tumors. J Leukoc Biol 70: 478-490.

Cunningham TJ. 1982. Naturally occurring neuron death and its regulation by developing neural pathways. Int Rev Cytol 74: 163-186.

DAHLBACK B. 2000. Blood coagulation. Lancet 355: 1627-1632.

Daleke DL. 2003. Regulation of transbilayer plasma membrane phospholipid asymmetry. J Lipid Res 44 : 233-242.

Daleke DL and Lyles JV. 2000. Identification and purification of aminophospholipid flippases. Biochim Biophys Acta 1486: 108-127.

De Freitas Balanco JM, Moreira ME, Bonomo A, Bozza PT, Amarante Mendes G, Pirmez C and BARCINSKI MA. 2001. Apoptotic mimicry by an obligate intracellular parasite downregulates macrophage microbicidal activity. Curr Biol 11: 1870-1873.
Devitt A, Moffatt OD, Raykundalia C, Capra JD, Simmons DL and Gregory CD. 1998. Human CD14 mediates recognition and phagocytosis of apoptotic cells. Nature 392: 505-509.

Devitt A, Pierce S, Oldreive C, Shingler WH and GrEGORY CD. 2003. CD14-dependent clearance of apoptotic cells by human macrophages: the role of phosphatidylserine. Cell Death Differ 10: 371-382.

DosReis GA And Barcinski MA. 2001. Apoptosis and parasitism: from the parasite to the host immune response. Adv Parasitol 49: 133-161.

ELlis RE, JACOBSON DM AND HoRvitz HR. 1991. Genes required for the engulfment of cell corpses during programmed cell death in Caenorhabditis elegans. Genetics 129: 79-94.

FAdOK VA AND Henson PM. 2003. Apoptosis: giving phosphatidylserine recognition an assist - with a twist. Curr Biol 13: R655-657.

Fadok VA, Voelker DR, Campbell PA, Cohen JJ, Bratton DL ANd Henson PM. 1992. Exposure of phosphatidylserine on the surface of apoptotic lymphocytes triggers specific recognition and removal by macrophages. J Immunol 148: 2207-2216.

Fadok VA, Bratton DL, Konowal A, Freed PW, Westcott JY and Henson PM. 1998. Macrophages that have ingested apoptotic cells in vitro inhibit proinflammatory cytokine production through autocrine/paracrine mechanisms involving TGF- $\beta$, $\mathrm{PGE}_{2}$, and PAF. J Clin Invest 101: 890-898.

Fadok VA, Bratton DL, Rose DM, Pearson A, EzeKewitz RA AND Henson PM. 2000. A receptor for phosphatidylserine-specific clearance of apoptotic cells. Nature 405: 85-90.

Fadok VA, de Cathelineau A, Daleke DL, Henson PM AND BRATton DL. 2001. Loss of phospholipid asymmetry and surface exposure of phosphatidylserine is required for phagocytosis of apoptotic cells by macrophages and fibroblasts. J Biol Chem 276: 1071-1077.

Fawcett J, Holness CL, Needham LA, Turley H, Gatter KC, Mason DY and Simmons DL. 1992. Molecular cloning of ICAM-3, a third ligand for LFA-1, constitutively expressed on resting leukocytes. Nature 360: 481-484.

Ferrero E, Jiao D, Tsuberi BZ, Tesio L, Rong GW, Haziot A and Goyert SM. 1993. Transgenic mice expressing human CD14 are hypersensitive to lipo- 
polysaccharide. Proc Natl Acad Sci USA 90: 2380-2384.

Fishelson Z, Attali G and Mevorach D. 2001. Complement and apoptosis. Mol Immunol 38: 207-219.

Franc NC, Dimarce JL, Lagueux M, Hoffmann J AND EzeKowitz RA. 1996. Croquemort, a novel Drosophila hemocyte/macrophage receptor that recognizes apoptotic cells. Immunity 4: 431-443.

Franc NC, White K and Ezekowitz RA. 1999a. Phagocytosis and development: back to the future. Curr Opin Immunol 11: 47-52.

Franc NC, Heitzler P, Ezekowitz RA and White K. 1999b. Requirement for croquemort in phagocytosis of apoptotic cells in Drosophila. Science 284: 19911994.

Freire de Lima CG, Nascimento DO, Soares MB, Bozza PT, Castro faria Neto HC, de Mello FG, DosReis GA AND Lopes MF. 2000. Uptake of apoptotic cells drives the growth of a pathogenic trypanosome in macrophages. Nature 403: 199-203.

Gershov D, Kim S, Brot N and Elkon KB. 2000. C-Reactive protein binds to apoptotic cells, protects the cells from assembly of the terminal complement components, and sustains an antiinflammatory innate immune response: implications for systemic autoimmunity. J Exp Med 192: 1353-1364.

Geske FJ and Gerschenson LE. 2001. The biology of apoptosis. Hum Pathol 32: 1029-1038.

Geske FJ, Monks J, Lehman L and Fadok VA. 2002. The role of the macrophage in apoptosis: hunter, gatherer, and regulator. Int J Hematol 76: 16-26.

Gilbreath MJ, Nacy CA, Hoover DL, Alving CR, Swartz GM AND Meltzer MS. 1985. Macrophage activation for microbicidal activity against Leishmania major: inhibition of lymphokine activation by phosphatidylcholine-phosphatidylserine liposomes. J Immunol 134: 3420-3425.

Ginestra A, La Placa MD, Saladino F, Cassara D, Nagase H ANd VitTorelli ML. 1998. The amount and proteolytic content of vesicles shed by human cancer cell lines correlates with their in vitro invasiveness. Anticancer Res 18: 3433-3437.

Ginestra A, Miceli D, Dolo V, Romano FM and VitTORELLI ML. 1999. Membrane vesicles in ovarian cancer fluids: a new potential marker. Anticancer Res 19: 3439-3445.
Green DR and Beere HM. 2000. Apoptosis. Gone but not forgotten. Nature 405: 28-29.

GrEgory CD. 2000. CD14-dependent clearance of apoptotic cells: relevance to the immune system. Curr Opin Immunol 12: 27-34.

Gumienny TL and Hengartner MO. 2001. How the worm removes corpses: the nematode $C$. elegans as a model system to study engulfment. Cell Death Differ 8: 564-568.

Gumienny TL, Lambie E, Hartwieg E, Horvitz HR AND Hengartner MO. 1999. Genetic control of programmed cell death in the Caenorhabditis elegans hermaphrodite germline. Development 126 : 1011-1022.

Gumienny Tl, Brugnera E, Tosello-Trampont AC, Kinchen JM, Haney LB, Nishiwaki K, Walk SF, Nemergut ME, Macara IG, Francis R, Schedl T, Qin Y, Aelst LV, Hengartner MO And RAVICHANDRAN KS. 2001. CED-12/ELMO, a novel member of the CrkII/Dock180/Rac pathway, is required for phagocytosis and cell migration. Cell 107: 27-41.

Hamon Y, Broccardo C, Chambenoit O, Luciani MF, Toti F, Chaslin S, Freyssinet JM, Devaux PF, MCNeish J, Marguet D and Chimini G. 2000. ABC1 promotes engulfment of apoptotic cells and transbilayer redistribution of phosphatidylserine. Nat Cell Biol 2: 399-406.

Hanayama R, Tanaka M, Miwa K, Shinohara A, IwaMATSU A AND Nagata S. 2002. Identification of a factor that links apoptotic cells to phagocytes. Nature 417: 182-187.

Hansen S AND Holmskov U. 1998. Structural aspects of collectins and receptors for collectins. Immunobiology 199: 165-189.

Hasegawa H, Kiyokawa E, Tanaka S, Nagashima K, Gotoh N, Shibuya M, Kurata T and Matsuda M. 1996. DOCK180, a major CRK-binding protein, alters cell morphology upon translocation to the cell membrane. Mol Cell Biol 16: 1770-1776.

Hawkins CJ, Wang SL and Hay BA. 1999. A cloning method to identify caspases and their regulators in yeast: identification of Drosophila IAP1 as an inhibitor of the Drosophila caspase DCP-1. Proc Natl Acad Sci USA 96: 2885-2890. 
Hengartner MO. 2000. The biochemistry of apoptosis. Nature 407: 770-776.

Hengartner MO. 2001. Apoptosis: corralling the corpses. Cell 104: 325-328.

Henson PM, Bratton DL and Fadok VA. 2001. The phosphatidylserine receptor: a crucial molecular switch? Nat Rev Mol Cell Biol 2: 627-633.

Hoffmann PR, deCathelineau AM, Ogden CA, LeVerrier Y, Bratton DL, Daleke DL, Ridley AJ, FAdok VA and Henson PM. 2001. Phosphatidylserine (PS) induces PS receptor-mediated macropinocytosis and promotes clearance of apoptotic cells. J Cell Biol 155: 649-659.

Holmskov U, Malhotra R, Sim RB and Jensenius JC. 1994. Collectins: collagenous C-type lectins of the innate immune defense system. Immunol Today 15 : $67-74$.

HoRviTz HR. 1999. Genetic control of programmed cell death in the nematode Caenorhabditis elegans. Cancer Res 59: 1701s-1706s.

Hughes J, Liu Y, Van Damme J and Savill J. 1997. Human glomerular mesangial cell phagocytosis of apoptotic neutrophils: mediation by a novel CD36independent vitronectin receptor/thrombospondin recognition mechanism that is uncoupled from chemokine secretion. J Immunol 158: 4389-4397.

Inaba K, Turley S, Yamaide F, Iyoda T, Mahnke K, Inaba M, Pack M, Subklewe M, Sauter B, Sheff D, Albert M, Bhardwaj N, Mellman I and Steinman RM. 1998. Efficient presentation of phagocytosed cellular fragments on the major histocompatibility complex class II products of dendritic cells. J Exp Med 188: 2163-2173.

Ishimoto Y, Ohashi K, Mizuno K and NaKano T. 2000. Promotion of the uptake of PS liposomes and apoptotic cells by a product of growth arrest-specific gene, gas6. J Biochem 127: 411-417.

JaCKson DE, Kupcho KR and Newman PJ. 1997. Characterization of phosphotyrosine binding motifs in the cytoplasmic domain of platelet/endothelial cell adhesion molecule-1 (PECAM-1) that are required for the cellular association and activation of the proteintyrosine phosphatase, SHP-2. J Biol Chem 272: 24868-24875.

Jiang Q, Akashi S, Miyake K and Petty HR. 2000. Lipopolysaccharide induces physical proximity be- tween CD14 and toll-like receptor 4 (TLR4) prior to nuclear translocation of NF-kappa B. J Immunol 165: 3541-3544.

Kerr JF, Wyllie AH And Currie AR. 1972. Apoptosis: a basic biological phenomenon with wide-ranging implications in tissue kinetics. Br J Cancer 26: 239257.

Kiyokawa E, Mochizuki N, Kurata T and Matsuda M. 1997. Role of Crk oncogene product in physiologic signaling. Crit Rev Oncog 8: 329-342.

KoRnBLUTH RS. 1994. The immunological potential of apoptotic debris produced by tumor cells and during HIV infection. Immunol Lett 43: 125-132.

Kurosaka K, Watanabe N and Kobayashi Y. 2001. Production of proinflammatory cytokines by resident tissue macrophages after phagocytosis of apoptotic cells. Cell Immunol 211: 1-7.

Lefkir Y, Malbouyres M, Gotthardt D, Ozinski A, Cornillon S, Bruc F, Aderem AA, Soldati T, Cosson P AND Letourneur F. 2003. Involvement of AP-1 adaptor complex in early steps of phagocytosis and macropinocytosis. Mol Biol Cell Nov 14 (Epub ahead of print).

Liu QA and Hengartner MO. 1998. Candidate adaptor protein CED-6 promotes the engulfment of apoptotic cells in C. elegans. Cell 93: 961-972.

Liu QA and Hengartner MO. 1999. Human CED-6 encodes a functional homologue of the Caenorhabditis elegans engulfment protein CED-6. Curr Biol 9: 1347-1350.

Luciani MF and Chimini G. 1996. The ATP binding cassette transporter $\mathrm{ABC} 1$, is required for the engulfment of corpses generated by apoptotic cell death. EMBO J 15: 226-235.

Mason RJ, Greene K and Voelker DR. 1998. Surfactant protein A and surfactant protein D in health and disease. Am J Physiol 275: L1.

Matsuno R, Aramaki Y and Tsuchiya S. 2001. Involvement of TGF- $\beta$ in inhibitory effects of negatively charged liposomes on nitric oxide production by macrophages stimulated with lps. Biochem Biophys Res Commun 281: 614-620.

McDonald PP, Fadok VA, Bratton D and Henson PM. 1999. Transcriptional and translational regulation of inflammatory mediator production by en- 
dogenous TGF- $\beta$ in macrophages that have ingested apoptotic cells. J Immunol 163: 6164-6172.

Mevorach D. 2000. Opsonization of apoptotic cells. Implications for uptake and autoimmunity. Ann NY Acad Sci 926: 226-235.

Mevorach D, Mascarenhas JO, Gershov D and ElKon KB. 1998. Complement-dependent clearance of apoptotic cells by human macrophages. J Exp Med 188: 2313-2320.

Miller YI, Viriyakosol S, Binder CJ, Feramisco JR, KirkLand TN and Witztum JL. 2003. Minimally modified LDL binds to CD14, induces macrophage spreading via TLR4/MD-2, and inhibits phagocytosis of apoptotic cells. J Biol Chem 278: 1561-1568.

Mills CD, Shearer J, Evans R and Caldwell MD. 1992. Macrophage arginine metabolism and the inhibition or stimulation of cancer. J Immunol 149: 2709-2714.

Moffatt OD, Devitt A, Bell ED, Simmons DL and GREGORY CD. 1999. Macrophage recognition of ICAM-3 on apoptotic leukocytes. J Immunol 162: 6800-6810.

Moreira ME, Del Portillo HA, Milder RV, Balanco JM AND BARCINSKI MA. 1996. Heat shock induction of apoptosis in promastigotes of the unicellular organism Leishmania (Leishmania) amazonensis. J Cell Physiol 167: 305-313.

NaKano T, Ishimoto Y, Kishino J, Umeda M, Inoue K, Nagata K, Ohashi K, Mizuno K and Arita H. 1997. Cell adhesion to phosphatidylserine mediated by a product of growth arrest-specific gene 6 . J Biol Chem 272: 29411-29414.

NASIRUdeEn AM, TAN KS, Singh M AND YAP EH. 2001. Programmed cell death in a human intestinal parasite, Blastocystis hominis. Parasitology 123: $235-246$.

Newman PJ. 1997. The biology of PECAM-1. J Clin Invest 99: 3-8.

Nitta T, Igarashi K and Yamamoto N. 2002. Polyamine depletion induces apoptosis through mitochondria-mediated pathway. Exp Cell Res 276: 120-128.

Nouri Shirazi M, Banchereau J, Bell D, Burkeholder S, Kraus ET, Davoust J and Palucka KA. 2000. Dendritic cells capture killed tumor cells and present their antigens to elicit tumor-specific immune responses. J Immunol 165: 3797-3803.
Ogden CA, deCathelineau A, Hoffmann PR, Bratton D, Ghebrehiwet B, FAdok VA and Henson PM. 2001. C1q and mannose binding lectin engagement of cell surface calreticulin and CD91 initiates macropinocytosis and uptake of apoptotic cells. J Exp Med 194: 781-795.

Ogier Denis E and Codogno P. 2003. Autophagy: a barrier or an adaptive response to cancer. Biochim Biophys Acta 1603: 113-128.

Oppenheim RW. 1991. Cell death during development of the nervous system. Annu Rev Neurosci 14: 453-501.

Pearson A, Lux A And Krieger M. 1995. Expression cloning of dSR-CI, a class $\mathrm{C}$ macrophage-specific scavenger receptor from Drosophila melanogaster. Proc Natl Acad Sci USA 92: 4056-4060.

PEARSON AM. 1996. Scavenger receptors in innate immunity. Curr Opin Immunol 8: 20-28.

Peiser L, De Winther MP, Makepeace K, HollinShead M, Coull P, Plested J, Kodama T, Moxon ER AND Gordon S. 2002. The class A macrophage scavenger receptor is a major pattern recognition receptor for Neisseria meningitidis which is independent of lipopolysaccharide and not required for secretory responses. Infect Immun 70: 5346-5354.

Pickering MC, Fischer S, Lewis MR, WAlport MJ, Botto M AND CoOK HT. 2001. Ultraviolet-radiation-induced keratinocyte apoptosis in C1q-deficient mice. J Invest Dermatol 117: 52-58.

Platt N, Suzuki H, Kurihara Y, Kodama T and GorDON S. 1996. Role for the class A macrophage scavenger receptor in the phagocytosis of apoptotic thymocytes in vitro. Proc Natl Acad Sci USA 93: 1245612460.

Platt N, DA Silva RP and Gordon S. 1998. Recognizing death: the phagocytosis of apoptotic cells. Trends Cell Biol 8: 365-372.

Platt N, Suzuki H, Kodama T and Gordon S. 2000. Apoptotic thymocyte clearance in scavenger receptor class A-deficient mice is apparently normal. J Immunol 164: 4861-4867.

Pradhan D, Krahling S, Williamson P and SchleGEL RA. 1997. Multiple systems for recognition of apoptotic lymphocytes by macrophages. Mol Biol Cell 8: 767-778. 
Pumphrey NJ, Taylor V, Freeman S, Douglas MR, Bradfield PF, Young SP, LoRd JM, WaKelam MJ, Bird IN, Salmon M ANd Buckley CD. 1999. Differential association of cytoplasmic signalling molecules SHP-1, SHP-2, SHIP and phospholipase C- $\gamma 1$ with PECAM-1/CD31. FEBS Lett 450: 77-83.

Ramprasad MP, Terpstra V, Kondratenko N, QueHeNBERGER O AND STEINBERg D. 1996. Cell surface expression of mouse macrosialin and human CD68 and their role as macrophage receptors for oxidized low density lipoprotein. Proc Natl Acad Sci USA 93: 14833-14838.

Reddien PW AND Horvitz HR. 2000. CED-2/CrkII and CED-10/Rac control phagocytosis and cell migration in Caenorhabditis elegans. Nat Cell Biol 2: 131-136.

Reiter I, Krammer B and Schwamberger G. 1999. Cutting edge: differential effect of apoptotic versus necrotic tumor cells on macrophage antitumor activities. J Immunol 163: 1730-1732.

Ren Y, Silverstein RL, Allen J and Savill J. 1995. CD36 gene transfer confers capacity for phagocytosis of cells undergoing apoptosis. J Exp Med 181: 1857-1862.

Ren Y, Stuart L, Lindberg FP, Rosenkranz AR, Chen Y, Mayadas TN and Savill J. 2001. Nonphlogistic clearance of late apoptotic neutrophils by macrophages: efficient phagocytosis independent of $\beta_{2}$ integrins. J Immunol 166: 4743-4750.

Ross GD. 2000. Regulation of the adhesion versus cytotoxic functions of the Mac-1/CR3/alphaMbeta2integrin glycoprotein. Crit Rev Immunol 20: 197222.

Rubartelli A, Poggi A and Zocchi MR. 1997. The selective engulfment of apoptotic bodies by dendritic cells is mediated by the $\alpha_{\mathrm{V}} \beta_{3}$ integrin and requires intracellular and extracellular calcium. Eur J Immunol 27: 1893-1900.

Sambrano GR and Steinberg D. 1995. Recognition of oxidatively damaged and apoptotic cells by an oxidized low density lipoprotein receptor on mouse peritoneal macrophages: role of membrane phosphatidylserine. Proc Natl Acad Sci USA 92: 1396-1400.

Sauter B, Albert ML, Francisco L, Larsson M, SomERSAN S AND BhardwaJ N. 2000. Consequences of cell death: exposure to necrotic tumor cells, but not primary tissue cells or apoptotic cells, induces the maturation of immunostimulatory dendritic cells. J Exp Med 191: 423-434.

Savill J AND FAdoK V. 2000. Corpse clearance defines the meaning of cell death. Nature 407: 784-788.

Savill J, Dransfield I, Hogg N and Haslett C. 1990. Vitronectin receptor-mediated phagocytosis of cells undergoing apoptosis. Nature 343: 170-173.

Savill J, Hogg N, Ren Y and Haslett C. 1992. Thrombospondin cooperates with CD36 and the vitronectin receptor in macrophage recognition of neutrophils undergoing apoptosis. J Clin Invest 90: 1513-1522.

Savill J, Dransfield I, Gregory C and Haslett C. 2002. A blast from the past: clearance of apoptotic cells regulates immune responses. 2: 965-975.

Schweichel JU And Merker HJ. 1973. The morphology of various types of cell death in prenatal tissues. Teratology 7: 253-266.

Scott RS, McMahon EJ, Pop SM, Reap EA, CaricChio R, COHEn PL, EARP HS And Matsushima GK. 2001. Phagocytosis and clearance of apoptotic cells is mediated by MER. Nature 411: 207-211.

Somersan S ANd Bhardwaj N. 2001. Tethering and tickling: a new role for the phosphatidylserine receptor. J Cell Biol 155: 501-504.

Sperandio S, de Belle I and Bredesen DE. 2000. An alternative, nonapoptotic form of programmed cell death. Proc Natl Acad Sci USA 97: 14376-14381.

Su HP, Nakada Tsukui K, Tosello Trampont AC, Li Y, Bu G, Henson PM and Ravichandran KS. 2002. Interaction of CED-6/GULP, an adapter protein involved in engulfment of apoptotic cells with CED-1 and CD91/low density lipoprotein receptorrelated protein (LRP). J Biol Chem 277: 11772 11779.

Sun J, Nanjundan M, Pike LJ, Wiedmer T and Sims PJ. 2002. Plasma membrane phospholipid scramblase 1 is enriched in lipid rafts and interacts with the epidermal growth factor receptor. Biochemistry 41 : 6338-6345.

Takano Ohmuro H, Mukaida M, Kominami E and MoriokA K. 2000. Autophagy in embryonic erythroid cells: its role in maturation. Eur J Cell Biol 79: 759-764.

Tatischeff I, Petit PX, Grodet A, Tissier JP, Duband Goulet I AND Ameisen JC. 2001. Inhibition of 
multicellular development switches cell death of Dictyostelium discoideum towards mammalian-like unicellular apoptosis. Eur J Cell Biol 80: 428-441.

Taylor PR, Carugati A, Fadok VA, CoOK HT, Andrews M, Carroll MC, Savill JS, Henson PM, Botto M And Walport MJ. 2000. A hierarchical role for classical pathway complement proteins in the clearance of apoptotic cells in vivo. J Exp Med 192: 359-366.

Teder P, Vandivier RW, Jiang D, Liang J, Cohn L, Pure E, Henson PM and Noble PW. 2002. Resolution of lung inflammation by CD44. Science 296: $155-158$.

Tepass U, Fessler LI, Aziz A and Hartenstein V. 1994. Embryonic origin of hemocytes and their relationship to cell death in Drosophila. Development 120: 1829-1837.

Thumm M, Egner R, Koch B, Schlumpberger M, Straub M, Veenhuis M and Wolf DH. 1994. Isolation of autophagocytosis mutants of Saccharomyces cerevisiae. FEBS Lett 349: 275-280.

Utsugi T, Schroit AJ, Connor J, Bucana CD AND FIDLER IJ. 1991. Elevated expression of phosphatidylserine in the outer membrane leaflet of human tumor cells and recognition by activated human blood monocytes. Cancer Res 51: 3062-3066.

Van Aelst L and D’Souza Schorey C. 1997. Rho GTPases and signaling networks. Genes Dev 11: 2295-2322.

van der Kleij D, Latz E, Brouwers JF, Kruize YC, Schmitz M, Kurt Jones EA, EspeviK T, DE Jong EC, Kapsenberg ML, Golenbock DT, Tielens AG AND YAZDANBAKHSH M. 2002. A novel host-parasite lipid cross-talk. Schistosomal lyso-phosphatidylserine activates toll-like receptor 2 and affects immune polarization. J Biol Chem 277: 48122-48129.

Vandivier RW, Ogden CA, Fadok VA, Hoffmann PR, Brown KK, Botto M, Walport MJ, Fisher JH, Henson PM ANd GReEne KE. 2002. Role of surfactant proteins $\mathrm{A}, \mathrm{D}$, and $\mathrm{C} 1 \mathrm{q}$ in the clearance of apoptotic cells in vivo and in vitro: calreticulin and CD91 as a common collectin receptor complex. J Immunol 169: 3978-3986.

Vardi A, Berman Frank I, Rozenberg T, Hadas O, Kaplan A And Levine A. 1999. Programmed cell death of the dinoflagellate Peridinium gatunense is mediated by $\mathrm{CO}(2)$ limitation and oxidative stress. Curr Biol 9: 1061-1064.

Verbovetski I, Bychkov H, Trahtemberg U, Shapira I, Hareuveni M, Ben Tal O, Kutikov I, Gill O and Mevorach D. 2002. Opsonization of apoptotic cells by autologous iC $3 \mathrm{~b}$ facilitates clearance by immature dendritic cells, down-regulates DR and CD86, and up-regulates CC chemokine receptor 7. J Exp Med 196: 1553-1561.

Viriyakosol S, Tobias PS, Kitchens RL AND KiRKLAND TN. 2001. MD-2 binds to bacterial lipopolysaccharide. J Biol Chem 276: 38044-38051.

Voll Re, Herrmann M, Roth EA, Stach C, KALDEN JR AND GiRKontaite I. 1997. Immunosuppressive effects of apoptotic cells. Nature 390: 350-351.

Wang CW And KLIONSKy DJ. 2003. The molecular mechanism of autophagy. Mol Med 9: 65-76.

WANG PY, Kitchens RL and Munford RS. 1998. Phosphatidylinositides bind to plasma membrane CD14 and can prevent monocyte activation by bacterial lipopolysaccharide. J Biol Chem 273: 24309-24313.

Wang X, Wu YC, Fadok VA, LeE MC, Gengyo-Ando K, Cheng LC, Ledwich D, Hsu PK, Chen JY, ChOU BK, Henson PM, Mitani S and Xue D. 2003. Cell corpse engulfment mediated by $C$. elegans phosphatidylserine receptor through CED-5 and CED-12. Science 302: 1563-1566.

White K, Grether ME, Abrams JM, Young L, FarRELl K AND STEller H. 1994. Genetic control of programmed cell death in Drosophila. Science 264: 677-683.

Williams GT and Smith CA. 1993. Molecular regulation of apoptosis: genetic controls on cell death. Cell 74: 777-779.

Wu YC and Horvitz HR. 1998a. C. elegans phagocytosis and cell-migration protein CED-5 is similar to human DOCK180. Nature 392: 501-504.

Wu YC AND Horvitz HR. 1998b. The C. elegans cell corpse engulfment gene ced-7 encodes a protein similar to ABC transporters. Cell 93: 951-960.

Wu YC, Tsai MC, Cheng LC, Chou CJ and Weng NY. 2001. C. elegans CED-12 acts in the conserved crkII/DOCK180/Rac pathway to control cell migration and cell corpse engulfment. Dev Cell 1: 491502 . 
ZAKERI Z. 1998. The study of cell death by the use of cellular and developmental models. In: LOCKSHIN RA et al. (Ed.), When Cells Die, New York: WileyLiss, p. 97-130.

Zhou Z, HARTwieg E ANd Horvitz HR. 2001a. CED-1 is a transmembrane receptor that mediates cell corpse engulfment in C. elegans. Cell 104: 43-56.
Zhou Z, Caron E, Hartwieg E, Hall A and Horvitz HR. 2001b. The C. elegans PH domain protein CED-

12 regulates cytoskeletal reorganization via a Rho/Rac GTPase signaling pathway. 1: 477-489. 